\title{
The Classification with Respect to Strobe Artifacts
}

\author{
M. A. Al-Askari
}

\begin{abstract}
An algorithm for estimating strobe effects on raster images is given. The algorithm is based on image segmentation in OpenCV $\mathrm{C}++$ using the Canny detector, for which its parameters are selected. The first group of parameters refers to the case when the selection of contours is carried out most fully. In the second case, the outline se-lection area is per-formed for the main part of the image. The parameters of the Canny detector are determined on the basis of a calcula-tion of the average bright-ness of the halftone image and its transformed version. As a result, two binary imag-es are compared, and a conclusion is made about the presence of strobe artifacts or their level in the image under study.
\end{abstract}

Keywords : image, Canny, contours, grayscale image, average brightness, OpenCV C++..

\section{INTRODUCTION}

Image quality analysis is quite an extensive topic. Many scientific papers consider this issue from different points of view. The author and his colleagues raised this issue in $[1,2]$. Strobe effects on images are often regarded as artifacts. In this connection, the problem arises of estimating strobe effects, for example, on raster images [3, 4]. The color of various surfaces may vary under the influence of operational and climatic factors. This also generates interest in such phenomena, which should be characterized and developed methods for assessing the quality of scanned images [5, 6, 7]. A special place is occupied by the direction of non-reference evaluation of blocking artifacts $[8,9,10,11]$, where significant results were obtained. Research is also continuing in comparative assessments of image quality [12,13]. Features of strobe effects on images makes it necessary to develop various algorithms and methods for assessing the quality of images. The author proposed some approaches to solving this issue $[3,4]$. This article discusses a slightly different approach, which may allow to performing the classification of the studied images according to the presence or absence of strobe effects on them.

Evaluation of images with pure colors or images with a small number of unique pixels should be distinguished into a separate fragment of the program code. It is believed that such images without any artifacts. The question of definition of images with the least distortions or visually

Revised Manuscript Received on October 15, 2019.

* Correspondence Author Russia absolutely without distortions is actual. For example, it is considered to be the image of the coats of arms of countries and cities of the world without distortion, or without noticeable distortion. The approach proposed in this article allows you to do this.

\section{ALgORITHM}

The theoretical basis of the proposed algorithm is research on the selection of the boundaries of images using the Canny detector $[14,15,16]$. Still applies such a calculated value as the arithmetic mean of the pixels of the halftone image. At a certain stage, the brightness of the halftone image is increased by the value of the average pixel value. Further calculations are made with respect to the halftone image with increased brightness. After that, find the binary image, as well as images defined by the Canny boundary detector. On the three obtained images, their centers of mass are determined to compare them with each other. The number of nonzero elements is also determined. It is assumed that in the presence of strobe effects, the center of mass will shift. This assumption is due to the fact that in determining the borders by the Canny method, some of the irrelevant pixels of the halftone images disappear due to the specially selected parameters of the Canny algorithm. In the case when the number of unique pixels of the investigated image is small, it is considered that the image is without any artifacts. The developed algorithm for assessing the presence of artifacts in raster images, primarily artifacts strobe effects is presented in the form of the following items.

1. Download a three-channel image of the RGB color model.

2. Convert RGB color image to grayscale.

3. Determine the number of unique pixels. If the number of unique pixels is less than a specified boundary value, then the image is considered to be without artifacts. The algorithm ends. Otherwise, go to the next step of the algorithm.

4. Determination of average brightness Average halftone image with its fixation.

5. Increasing the brightness of the halftone image by half the average brightness calculated in the previous step.

6. Convert a new halftone image to a binary version. Determination of the center of mass of the binary image.

7. The definition of the first pair (1st_Canny) of the parameters of the Canny method: [0] - [Average]. 
Halftone image processing using the Canny method with 1st_Canny parameters. Determination of the number of nonzero elements nnzCannyl and the center of mass of the resulting binary image.

8. The definition of the second pair (2nd_Canny) of the parameters of the Canny method: [255 - Average] [255]. Halftone image processing using the Canny method with parameters 2nd_Canny. Determination of the number of nonzero elements nnzCanny 2 and the center of mass of the resulting binary image.

9. Calculation of the initial numerical metrics (Metrics): if nnzCanny1 is not equal to zero, then Metrics = 1 nnzCanny2 / nnzCanny1 and go to the next step of the algorithm, otherwise Metrics $=0$ and completion of the algorithm.

10. The definition of the 1 st corrective factor Cor 1 in the form of the ratio of the number of unique pixels of a halftone image to 255 .
11. The definition of the 2 nd correction factor Cor 2 as a result of the analysis of the centers of mass of the created binary images, which lies in $[0 ; 1]$.

12. ResultMetrics $=$ Metrics $*$ Cor $1 *$ Cor 2 result metric calculation.

13. The eleventh paragraph of the algorithm related to the analysis of the center of mass of binaration of the images on the $\mathrm{x}$-axis and the $\mathrm{y}$-axis.

\section{THE RESULTS OF APPLYING THE PROPOSED ALGORITHM TO TEST IMAGES}

The application of the algorithm was carried out on two groups of images: the first has noticeable distortions with strobe effects artifacts; the second is without visible distortion. Image quality assessment was carried out according to a program written in Win32 API $\mathrm{C}++$ and the computer vision library OpenCV in Microsoft Visual Studio 2015 environments.

The images (with scaled-down dimensions) of the first group are shown in Figure 1, the second in Figure 2.

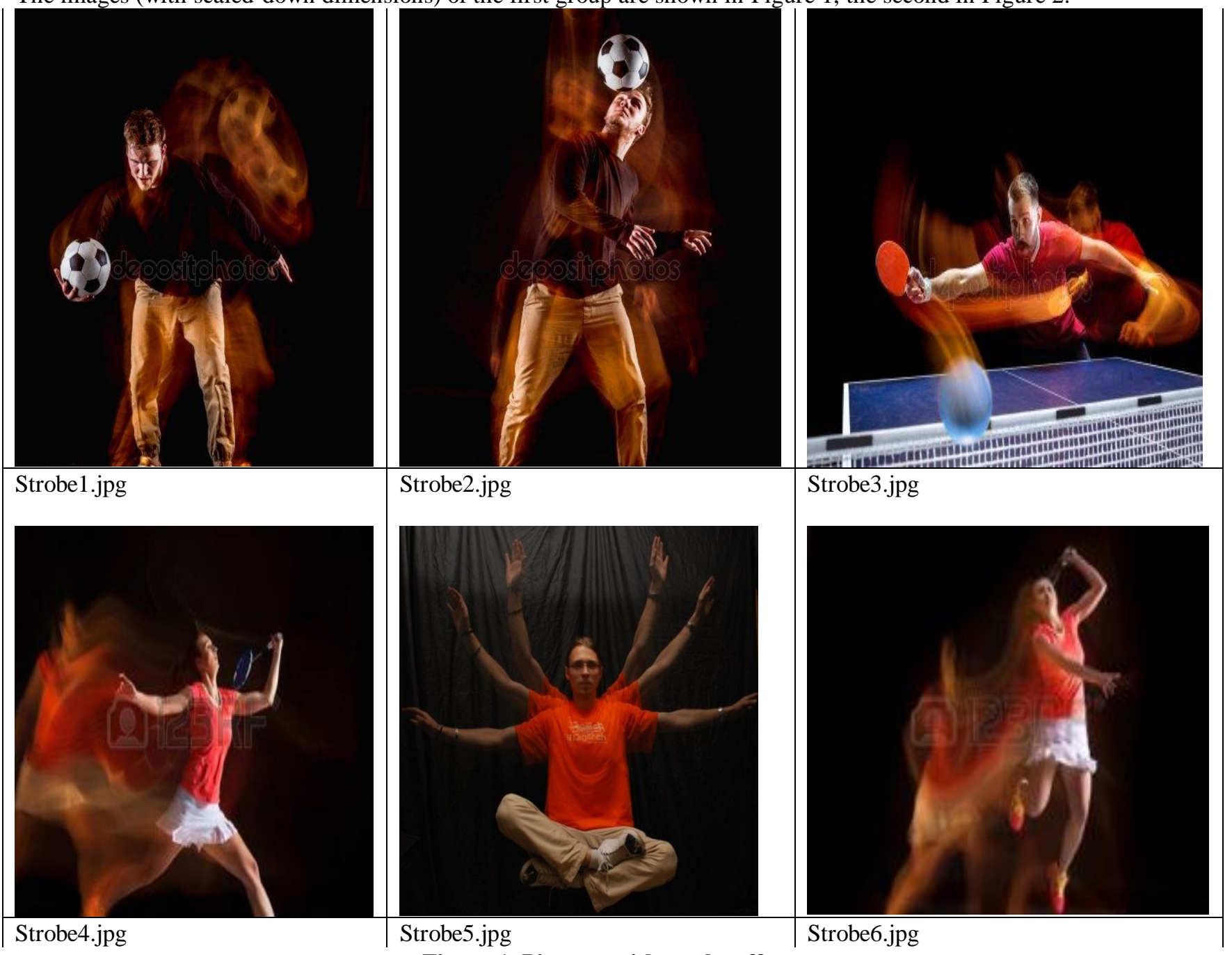

Figure 1. Pictures with strobe effects 


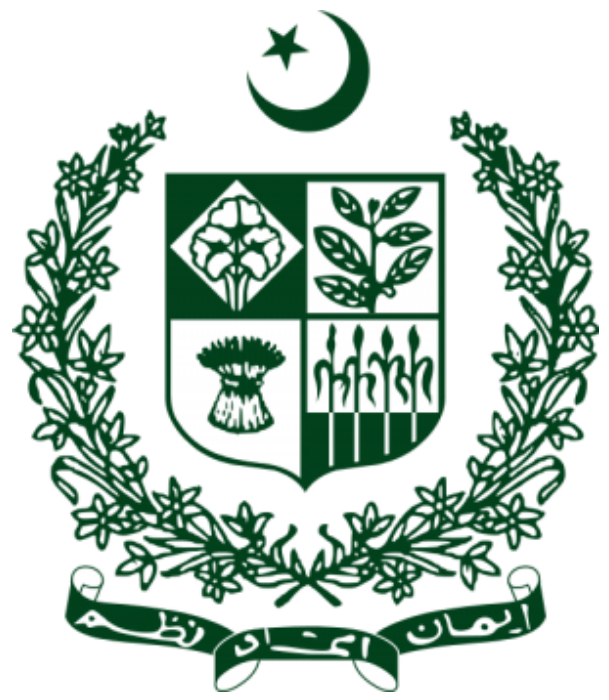

Pakistan.png

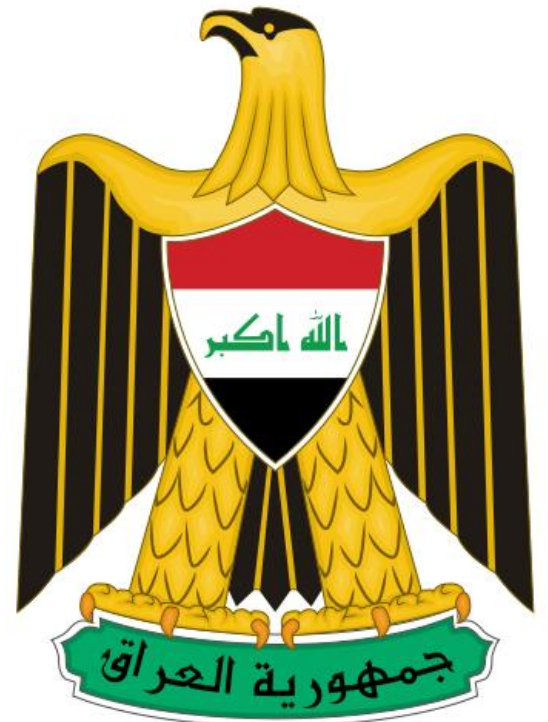

Iraq.bmp

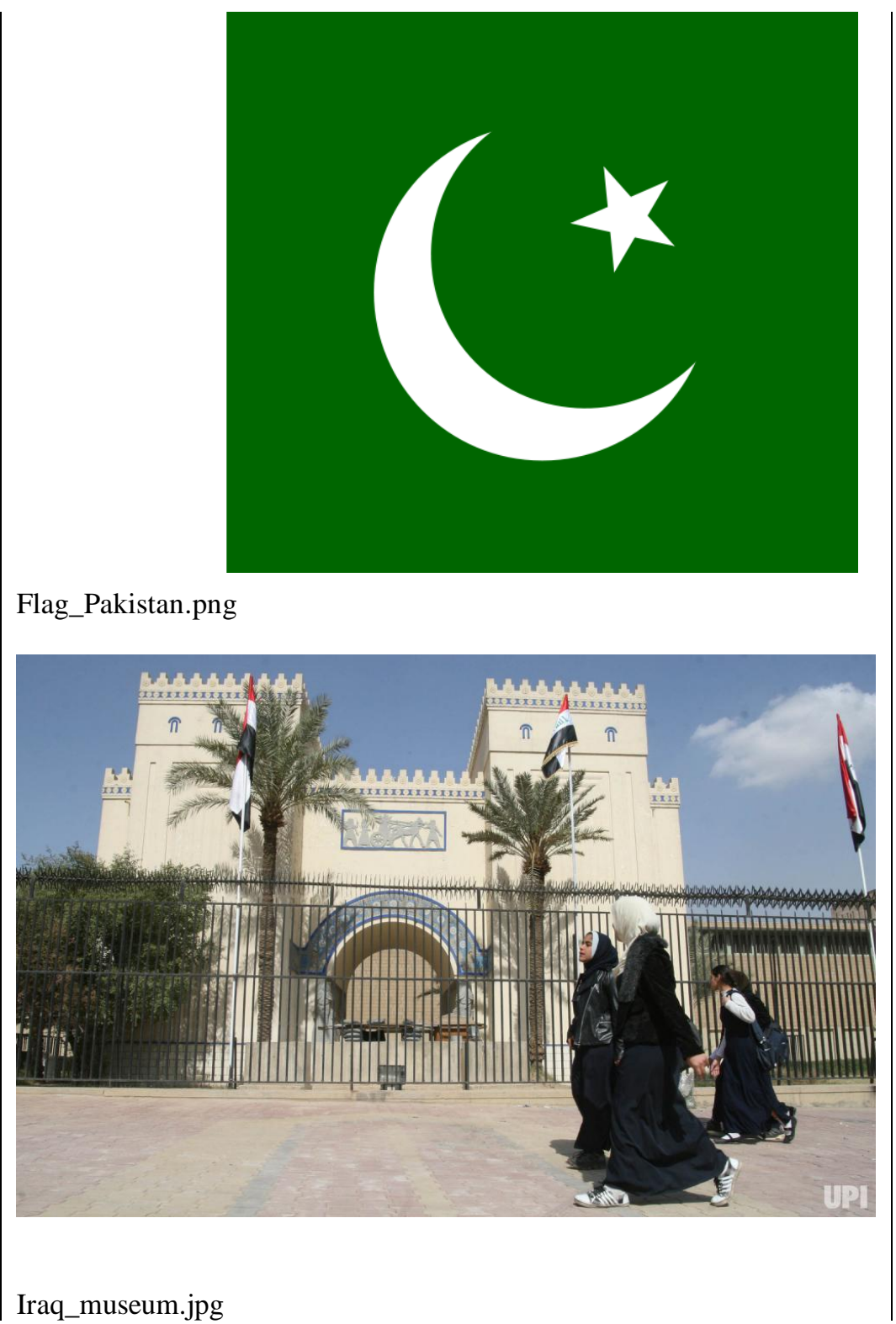

Figure 2. Images without visible artifacts

The specific types of binary images that are generated as a result of the analysis of the quality of the images shown in Figures 3 (Strobe4.jpg) and 4 (Pakistan.png).

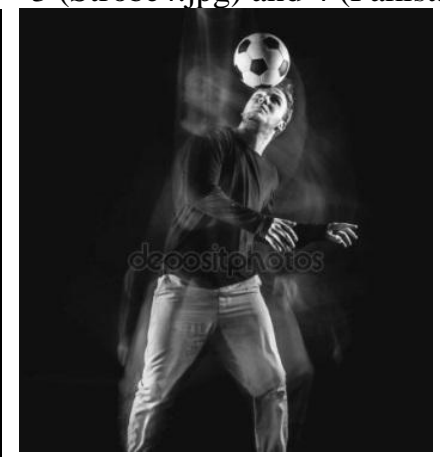

Gray

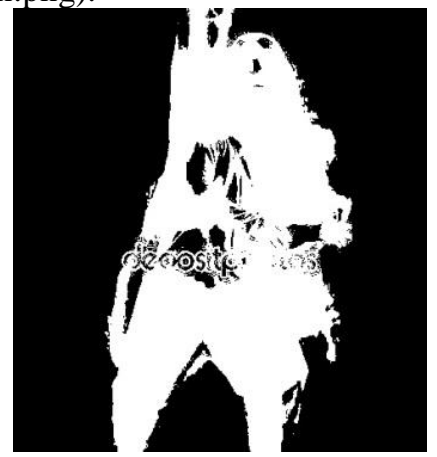

Black and white

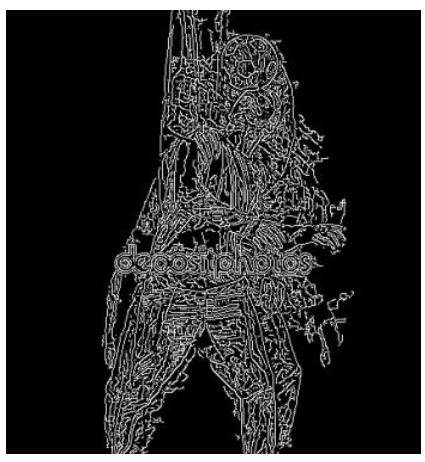

1stCanny

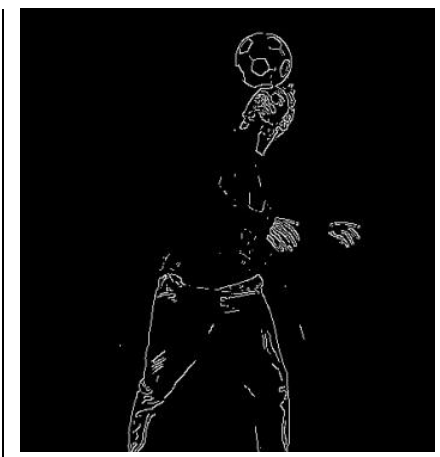

2ndCanny

Figure 3. Image processing with strobe effects in the proposed algorithm

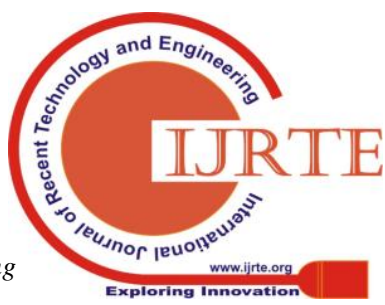




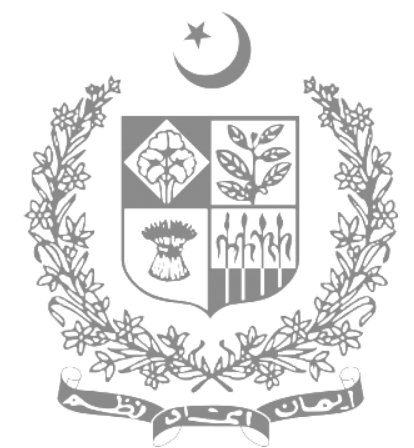

Gray.png

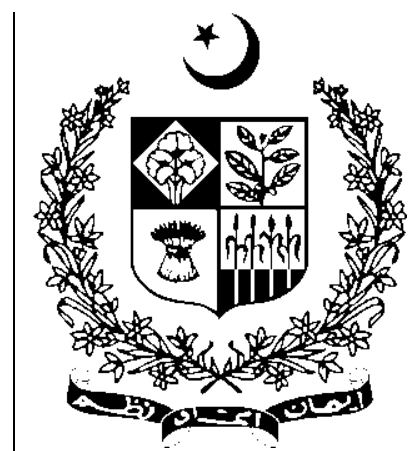

Black and white

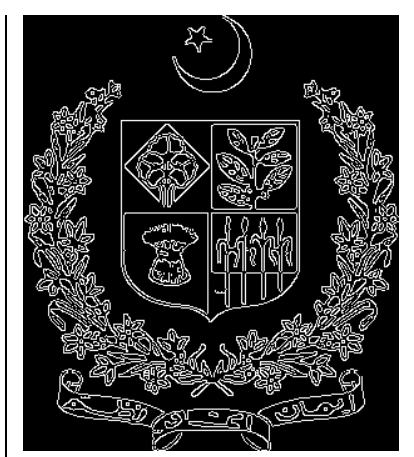

1stCanny

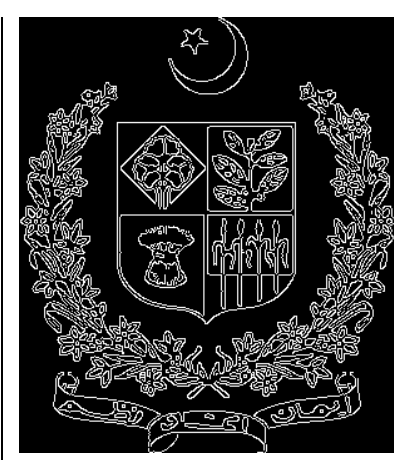

2ndCanny

Figure 4. Image processing without artifacts in the proposed algorithm

The results of software analysis of the quality of test images are summarized in Tables 1 and 2 .

Table 1: The results of processing the 1st group of test images.

\begin{tabular}{|l|l|l|l|l|l|l|}
\hline Results & Strobe1.jpg & Strobe2.jpg & Strobe3.jpg & Strobe4.jpg & Strobe5.jpg & Strobe6.jpg \\
\hline ResultMetrics & 0.720896 & 0.815542 & 0.496691 & 0.839980 & 0.613101 & 0.707649 \\
\hline Cor1 & 0.956863 & 0.968627 & 1.003922 & 1.000000 & 0.752941 & 1.000000 \\
\hline Cor2 & 0.887344 & 0.994979 & 0.899518 & 0.979000 & 0.846087 & 0.836725 \\
\hline
\end{tabular}

Table 2: The results of processing the 2 nd group of test images.

\begin{tabular}{|l|l|l|l|l|}
\hline Results & Pakistan.png & Flag_Pakistan.png & Iraq.bmp & Iraq_museum.jpg \\
\hline ResultMetrics & 0.005866 & 0.000000 & 0.013318 & 0.332962 \\
\hline Cor1 & 0.843137 & 0.764706 & 1.003922 & 1.000000 \\
\hline Cor2 & 0.986891 & 0.996745 & 0.990363 & 0.965771 \\
\hline
\end{tabular}

As can be seen from the above results in Tables 1 and 2, numerical metrics for assessing image quality are probabilistic estimates. When the metric approaches 1 , this means a high probability of the presence of artifacts of strobe effects in the image. Images with small metric values should be viewed with less distortion. There are ideal images, for them the metric is zero (for example, the flag of Pakistan). Other values suggest that there are distortions in the images. In general, according to this algorithm, images with a low level of distortion will be in the case when the metric values are less than 0.5. Although it should be recognized that the probability of 0.5 is extremely uncertain in its information content.

\section{Conclusion}

The considered algorithm was obtained as a result of numerous studies on digital image processing. Perhaps the novelty of this algorithm is the choice of parameters for the Canny algorithm, as well as the development of correction factors for the calculation of the metric in the form of the probability of assessing the quality of bitmaps.

This algorithm is a non-reference algorithm for assessing image quality, since it does not make a comparison with a reference image. At the same time, the author does not claim the universality of the developed algorithm. As the analysis of literary sources [1-16] and Internet sources shows, studies are conducted in various directions of determining artifacts in images.

\section{REFERENCES}

1. Аль-Аскари М. А., Федосин С. А., Афонин В. В. Анализ качества растровых изображений // Научно-технический вестник Поволжья. №1, 2018. С. 107-109.

2. Аль-Аскари М. А, Федосин С. А., Афонин В. В. Вероятностная оценка качества растровых изображений // Научно-технический вестник Поволжья. 2018. №4. С. $62-65$.

3. M. A. Al-Askari. Evaluation of strobe effects on bitmap images // Вестник Астраханского государственного технического университ

ета. Серия: Управление, вычислительная техника и информатика 2018. № 4. C. 80-89. doi: $10.24143 / 2072-9502-2018-4-80-89$.

4. Аль-Аскари М.А. Разработка числовых метрик оценки строб-эффектов наизображениях // Естественные и технические науки. 2018. №8. С.222-227.

5. Ерофеев В. Т., Афонин В. В., Черушова Н. В., Зоткина М. М., Митина Е. А., Зоткин В. Б., Ерофеева И. В. Методы и алгоритмы оценки качества поверхности строительных изделий и конструкций // Фундаментальные исследования. - 2016. - №4-1. - С. 33-40.

6. Ерофеев В.Т., Афонин В.В., Касимкина М.М. Влияние пластификаторов на изменение цветности ЛКМ под воздействием агрессивных сред // Лакокрасочные материалы и их применение. 2011. № 6. C. 38-41.

7. Черушова Н.В., Митина Е.А., Касимкина М.М., Афонин В.В., Ерофеев В.Т. Оценка изменения декоративных свойств лакокрасочных материалов под воздействием эксплуатационных факторов // Вестник Мордовского университета. 2008. № 4. С. 124-127.

8. Al-Askari M. A. The definition of artifacts of the type of blocking on raster images // Информационные технологии. Проблемы и решения.Уфа: Изд-во УГНТУ, 2018. Том 1(5). С. 83-87.

9. Hantao Liu and Ingrid Heynderickx. A no-reference perceptual blockiness metric // IEEE International Conference on Acoustics, Speech and Signal Processing 2008. Pages: 865-868.

10. Yan Fu and Shengchun Wang. A No Reference Image Quality Assessment Metric Based on Visual Perception // Algorithms 2016, 9(4), 87; doi:10.3390/a9040087.

11. K. Gu, J. Zhou, G. Zhai, W. Lin and A. C. Bovik. «No-reference quality assessment of screen content pictures», IEEE Transactions on Image Processing, vol. 26, no. 8, pp. 4005-4017, August, 2017.

12. K. Egiazarian, J. Astola, N. Ponomarenko, V. Lukin, F. Battisti, and M. Carli. «New full-reference quality metrics based on HVS», Proc. of the Second International Workshop on Video Processing and Quality Metrics, Scottsdale, 4 p, 2006.

13. H. Yeganeh and Z. Wang, «Objective quality assessment of tone-mapped images», IEEE Trans. Image Processing, vol. 22, pp. 657-667, Feb. 2013.

14. Canny, John, "A Computational Approach to Edge Detection," IEEE Transactions on Pattern Analysis and Machine Intelligence, Vol. PAMI-8, No. 6, 1986, pp. 679-698.

15. Lim, Jae S., Two-Dimensional Signal and Image Processing, Englewood Cliffs, NJ, Prentice Hall, 1990, pp. 478-488.

16. Parker, James R., Algorithms for Image Processing and Computer Vision, New York, John Wiley \& Sons, Inc., 1997, pp. 23-29.

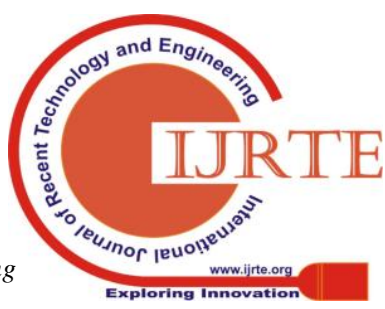

